\title{
Three new mountain national parks for Uganda
}

\author{
Thomas M. Butynski and Jan Kalina
}

For many years the Fauna and Flora Preservation Society has supported efforts to conserve forests in the Albertine Rift Afromontane Region of east-central Africa. The biodiversity of these forests is especially high but most have been destroyed or badly degraded. There are a large number of local, national and international initiatives to conserve at least some of the forests that remain. In 1991 Uganda created the Rwenzori Mountains, Mgahinga Gorilla, and Bwindi-Impenetrable National Parks, thus protecting all three of its Albertine Rift montane forests. This paper presents a synopsis of the conservation values of these three parks, and describes the conservation problems and the efforts to help ensure their proper development and long-term viability. Considerable progress towards the conservation of all three areas has already been made and future prospects are good, particularly for the mountain gorilla Gorilla gorilla beringei.

\section{Background}

Forests of the Albertine Rift Afromontane Region once covered most of what is today south-western Uganda, eastern Zaire, western Rwanda and western Burundi. During the last 130 years or so, these forests have been destroyed and fragmented by farmers (Butynski, 1984; Hamilton, 1984; Struhsaker, 1987; Tabor et al., 1990). None the less, the remaining forest blocks continue to support the richest montane fauna on the continent, including many endemics (Kingdon, 1971; MacKinnon and MacKinnon, 1986), and are of great importance for the conservation of Africa's biodiversity.

The region harbours some of the highest human population densities in Africa (100-450 people $/ \mathrm{sq} \mathrm{km}$ ). These populations continue to grow rapidly, putting more and more pressure on what forest remains. Steeper and steeper slopes are being cleared of trees, leading to increased water run-off and consequent soil erosion, crop damage, flooding and siltation. Forest products, such as lumber and firewood, are becoming scarce or unavailable (Butynski, 1984; Hamilton, 1984; Struhsaker, 1987; UNEP, 1988b).

Tropical moist forests probably covered more than 20 per cent (c. $39,000 \mathrm{sq} \mathrm{km}$ ) of Uganda's land surface before human clearance (Hamilton, 1984; Howard, 1991). By 1986 forest cover had been reduced by at least 87 per cent to about $5000 \mathrm{sq} \mathrm{km}$ (UNEP, 1988b). Based upon the information currently available, we estimate that Uganda now has somewhere between 4200 and $5000 \mathrm{sq} \mathrm{km}$ of tropical moist forest, accounting for less than 2.6 per cent of its land surface. There is now virtually no tropical moist forest to be found outside forest reserves and national parks. None the less, Hamilton (1984) estimated that some 2 per cent of the nation's tropical moist forest continues to be lost annually. Unless the current trend is broken, Uganda will have only about $4000 \mathrm{sq} \mathrm{km}$ of tropical moist forest by the year 2000 (FAO and UNEP, 1981).

Why has Uganda lost so much forest so fast? The causes are a complex of environmental, economic, political, social and historical factors. Several papers and reports discuss these in detail (for example, Hamilton, 1984; Struhsaker, 1987; UNEP, 1988b, 1988c; Tabor et al., 1990; Howard, 1991). It is not our intention to review this issue but we reiterate what many others have already concluded: the rootcause of the problem is overpopulation. 
The issue of human population growth in Uganda must be confronted if its forests are to survive. 'Uganda needs, as a matter of urgency, to take steps to limit the size of its population and to introduce systems of land use which utilize resources more efficiently than is the case today' (Hamilton, 1984). 'There is patently a need for population policies that match [Uganda's] growth with available resources' (UNEP, 1988a). 'Until human population control becomes a major national priority, there is little chance of meeting the subsistence requirements of the people, much less improving their standard of living. The current degradation of Uganda's forest resource is one of the first and most deleterious consequences of the human population explosion' (Struhsaker, 1987). 'The impacts of an increasing population on any developing country, and especially on Uganda, are enormous. Continued high rates of population growth will systematically undermine all programmes aimed at restoring and improving economic development, and will continue to deplete the basic resource base of the country in environmentally unsound ways' (UNEP, 1988c).

Uganda's human population is now growing at a rate of about 3 per cent annually. The population doubled between 1960 and 1987, and will double again by the year 2000 (Hamilton, 1984). At the present rate of growth, there will be a 19-fold increase during the next century. World Bank (1985) and UNEP (1988c) stated that Uganda has already exceeded its population carrying capacity.

The present high rate of growth is having an acute negative effect on the resources available to each Ugandan. For example, in 1948 there were 3.6 ha of arable land per person; in 1984 there were 1.4 ha per person; and at the turn of the century there will be less than 0.6 ha per person. In addition, the land will probably be far less productive. Uganda is obviously experiencing a shortage of land, trees and other resources. This is having a catastrophic effect on the environment and, therefore, on the potential for long-term development and on the well-being of the people.

Some might claim that Uganda would not be considered overpopulated if its social and economic situation and resource management practices were to change. Perhaps so, but the changes would have to be soon and dramatic. There is no such 'revolution' on the horizon.

The Government of Uganda is aware of the country's environmental problems and conservation needs. The 'Kampala Commitment to Sustainable Development in Africa' (June 1989) emphasized that Uganda is committed to species and ecosystem conservation through sustainable management.

Given the political, social, economic and military problems of the 1970s and early 1980s, coupled with a rapidly expanding human population, it was not possible for the Uganda government to protect properly, manage or develop its natural resources. Today, working under much improved circumstances and with considerable local interest and international assistance, Uganda is developing progressive programmes for the management of its natural resources and its human population. This vigorous movement is being led by the highest levels of government.

\section{Three new mountain national parks}

Three of the montane forests of the Albertine Rift Afromontane Region lie within Uganda. All are of astonishing beauty, immeasurable scientific significance, and great economic and ecological importance. Since the present government came to power in 1986 there have been a number of initiatives designed to ensure the long-term survival of these montane forests and in 1991 the government established these forests as national parks. From a world-wide perspective this was a major conservation achievement.

Mgahinga Gorilla National Park, Rwenzori Mountains National Park, and BwindiImpenetrable National Park are the first forested national parks in an already diverse and impressive national parks system (Figure 1). They bring to the Uganda national parks system four ecosystems and nine vegetation types not previously represented (LangdaleBrown et al., 1964; Baranga, 1990). 


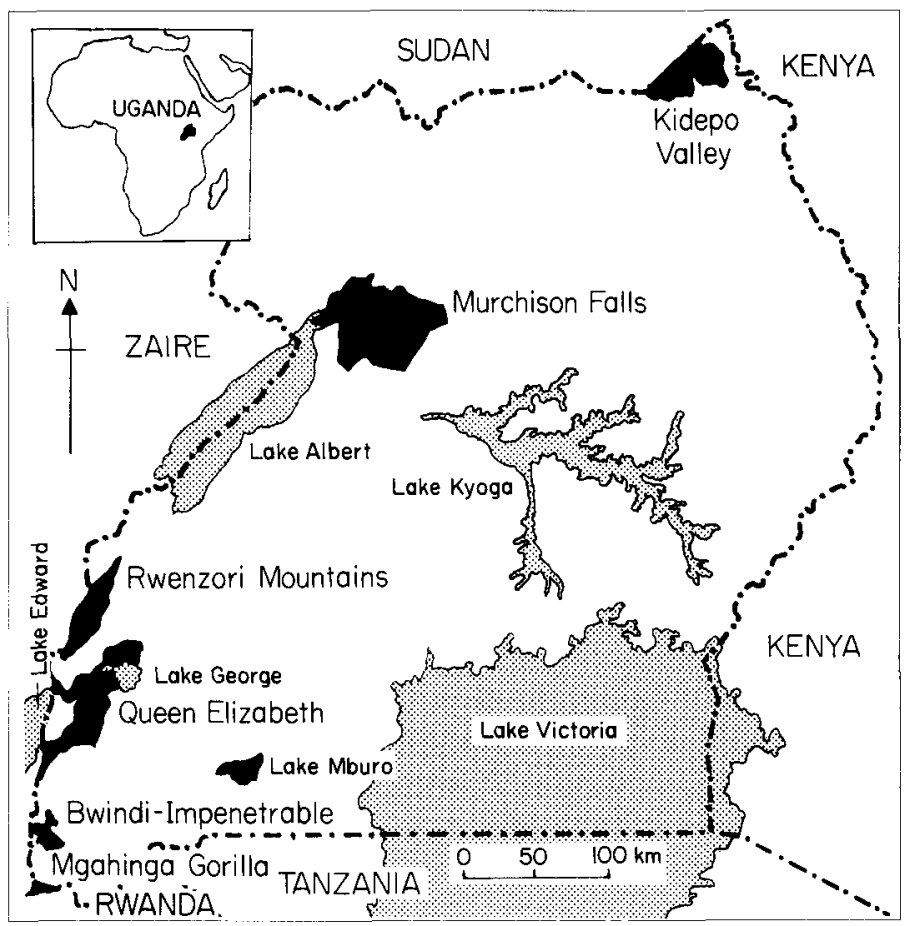

Figure 1. Map showing the locations of Uganda's seven national parks and the five largest lakes in the region.

\section{Overview of the three new parks}

Destruction of forest outside the boundaries of Rwenzori, Mgahinga and Bwindi-Impenetrable Forests is nearly complete and, thus, the three parks provide rare local examples of relatively natural ecosystems.

All three parks lie near the source of the Nile and protect water catchments vital to a large number of people, which makes water conservation and catchment protection perhaps the most obvious and important reasons for protecting these forests.

Products removed from all three forests include bamboo, poles, firewood, timber, medicinal plants, honey and bushmeat. In many cases the extraction of these materials has not been sustainable, has not benefited local communities as a whole, and has caused unnecessary damage to the ecosystem.

All three forests have experienced similar conservation problems (Malpas and Infield, 1981; Butynski, 1984; Howard, 1991; Werikhe, 1991; Kalina, 1993; Butynski et al., in press). These included: damage to the vegetation and watershed; theft of fuelwood, timber, bamboo and poles; illegal grazing; smuggling of cattle, lumber and gold; agricultural encroachment; and poaching. Several species of timber trees have been over-exploited. Elephant Loxodonta africana, buffalo Synceros caffer and leopard Panthera pardus have been extirpated, or nearly so. In the Bwindi-Impenetrable Forest, for example, buffalo and leopard no longer occur and fewer than 30 elephants remain (Butynski, 1984, 1985). Road and dam construction, and illegal gold mining, were additional problems in the Bwindi-Impenetrable Forest. In Rwenzori, there are problems associated with tourist activities, such as litter, sanitation, soil erosion and damage to the fragile vegetation along footpaths.

All three forests hold great potential for generating tourism and its associated economic benefits. Many visitors say that the Rwenzori surpasses Mt Kenya and Mt Kilimanjaro in beauty, interest, and mountaineering experience. The Bwindi-Impenetrable Forest, with its mountain gorillas, high species diversity and varied forest types (lowland, 
Illegal gold mining in the BwindiImpenetrable Forest caused considerable damage to the vegetation, disturbed wildlife populations and created dangerous pits. This is one of several illegal activities that park rangers, with support from FFPS, were able to stop (Tom Butynski).

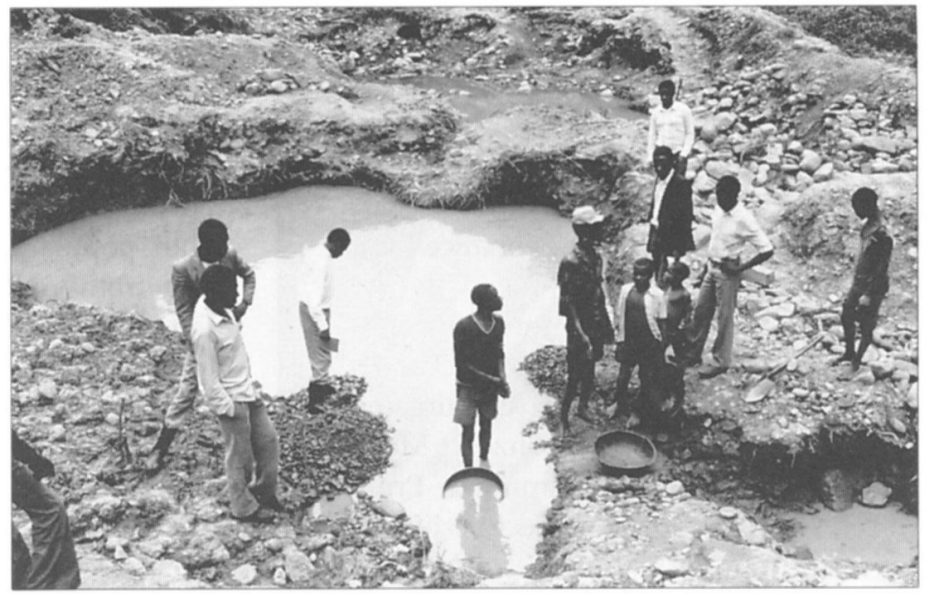

medium altitude and montane forests), has the potential to be Uganda's premier tourist attraction. Mgahinga, with its mountain gorillas and spectacular volcanoes, is also highly attractive to tourists.

Solving conservation problems in Uganda's montane forests and establishing sustainable resource use are difficult and expensive undertakings. Fortunately, international conservation and development organizations and agencies are working with local communities and the government to meet this challenge.

\section{Rwenzori Mountains National Park}

\section{Scenery and wildlife}

The Rwenzori Mountains National Park (formerly Rwenzori Forest Reserve) encompasses the fabled 'Mountains of the Moon' of ancient Greek geographers. This $996-\mathrm{sq}-\mathrm{km}$ park is contiguous with Zaire's Park National des Virunga (Figure 1). About 80 per cent of the steep and rugged Rwenzori Range lies in Uganda. With an altitudinal range of 1700-5109 $\mathrm{m}$, it holds the third highest peak in Africa (Mt Margherita) and the highest reaches of the park are covered by snow fields and glaciers. Although not as high as $\mathrm{Mt}$ Kilimanjaro, and a little less high than Mt Kenya, Rwenzori supports a far more extensive alpine area than either of these.
Four vegetation zones are distinguishable: montane forest, bamboo, tree heather and alpine. In the region, only the Rwenzori Mountains and the Virunga Volcanoes are high enough to support alpine vegetation, which makes them of particular significance for biodiversity conservation.

The plants in the tree heather and alpine zones of the Rwenzori are of particular interest, with many species endemic either to this massif or to the Albertine Rift. The giant heathers, ericas, groundsels and lobelias are especially striking (Osmaston and Pasteur, 1972; Howard, 1991; Yeoman, 1992). Indeed, for most visitors and scientists, it is the flora rather than the fauna that is of greatest interest.

The Rwenzori holds at least 89 species of forest birds, 19 of which are endemic to the Albertine Rift Afromontane Region (DowsettLemaire and Dowsett, 1990). Eleven species of large mammals occur: regional endemic or threatened species found in this park include the elephant, chimpanzee Pan troglodytes, l'Hoest's monkey Cercopithecus l'hoesti, Rwenzori black-and-white colobus Colobus angolensis ruwenzorii, Rwenzori tree hyrax Dendrohyrax arboreus ruwenzorii and Rwenzori leopard Panthera p. ruwenzorii (Howard, 1991).

\section{Conservation in the Rwenzori}

With support from the United States Agency for International Development (USAID), 
Rwenzori Mountaineering Services is providing logistic support to tourists and developing facilities along the main tourist routes. These include new huts, walkways, bridges, signposts and paths. This project is directing financial benefits derived from tourism to the local people in an effort to enhance local support for the new park.

The World Wide Fund for Nature (WWF), with financial support from USAID and in collaboration with Rwenzori Mountaineering Services, started the Rwenzori Mountains Conservation and Development Project in May 1991. The primary objective of this project is to improve natural resources management. During its first 2 years it established a conservation education programme, provided equipment and other support to national parks staff, and worked with government, local authorities and communities to determine the conservation and development priorities for the park and the surrounding area.

\section{Mgahinga Gorilla National Park}

\section{Scenery and wildlife}

The Mgahinga Gorilla National Park (formerly Gorilla Game Reserve and Mgahinga Forest Reserve) covers $34 \mathrm{sq} \mathrm{km}$ on the northern slopes of three of the Virunga (Bufumbira) Volcanoes (Muhavura, Mgahinga and Sabinyo) and is contiguous with Rwanda's Parc National des Volcans (160 sq km) and Zaire's Parc National des Virunga-Sud $(240 \mathrm{sq} \mathrm{km})$ (Figure 1). Together, they form the much larger Virunga Conservation Area (434 sq $\mathrm{km})$. With an altitudinal range of $2227-4127$ $\mathrm{m}$, this park offers spectacular scenery. Montane forest, bamboo, tree heather and alpine are the four main vegetation zones.

One of the main reasons for establishing this park was to improve protection for mountain gorillas. At least 42 gorillas in eight groups, plus two lone adult males, used the Mgahinga Forest in 1989-90 (Butynski et al., in press).

Of the three subspecies of gorilla, the mountain gorilla is the most endangered (Lee et al., 1988), occuring only in the Virunga Volcanoes and in the Bwindi-Impenetrable National Park. The world population numbers only about about 620 , with $309-340$ in the Virunga Volcanoes Conservation Area (Sholley, 1990) and about 300 in the Bwindi-Impenetrable Forest (T. M. Butynski, unpubl. data). While both populations receive considerable attention from governments, conservationists and the public, both continue to be threatened due to their small population sizes, susceptibility to diseases, and continued pressure on their habitats by agriculturalists.

There are at least 400 species of plants in the Virunga Volcanoes (Kalina, 1993; M. Rejmanek, pers. comm.). The volcanoes are home to the rare and beautiful golden monkey Cercopithecus mitis kandti and at least 185 species of birds (Kalina, 1993), 16 of which are endemic to the Albertine Rift Afromontane Region; three are threatened with extinction (Collar and Stuart, 1985; Dowsett-Lemaire and. Dowsett, 1990).

\section{Conservation in Mgahinga}

Since the 1950s the conservation value of the Mgahinga Forest has declined as a result of large-scale encroachment by agriculturalists and high levels of other illegal activities. In the early 1950s farmers encroached upon the lower, northern 29 per cent $(10 \mathrm{sq} \mathrm{km}$ ) of the forest and replaced the best gorilla habitat in the reserve with crops (Malpas and Infield, 1981; Butynski et al., in press).

In January 1989 the Impenetrable Forest Conservation Project (IFCP) established a subproject at Mgahinga: the Gorilla Game Reserve Conservation Project (now the Mgahinga Gorilla National Park Project). Financial support was provided by FFPS, WWF, the African Wildlife Foundation, USAID, the German Animal Protection Society, Berggorilla Patenschaft, and more recently the Centre for International Migration and Development.

The Uganda Government, Mgahinga Gorilla National Park Project, IFCP and CARE's Development Through Conservation Project (DTCP) have together made considerable progress in developing a broad-based conservation programme for managing and protect- 
ing the Mgahinga Forest. The following is a summary of the more important achievements between January 1989 and April 1993.

* An ecological survey of the large mammals, with a focus on the gorilla, was completed (Werikhe, 1991; Butynski et al., in press).

* A ranger camp and project headquarters were built and the park ranger/warden force was increased from three to 33 men. All are now well equipped and trained. At least 6550 wire traps were destroyed (Werikhe, 1991; K.J. Sucker, pers. comm.). We are reasonably certain that no gorillas or elephants have been poached since January 1989.

* In 1989-1990 DTCP conducted biological inventory work at Mgahinga.

* In 1990 a tour company was prevented from gaining a monopoly over future tourism activities. The company sought to establish a lodge in the middle of this small conservation area and completely control gorilla tourism.

* The conservation status of the Mgahinga Forest was up-graded to that of a national park, using the original (1930) boundaries of the Gorilla Game Reserve and Mgahinga Forest Reserve, including the $10 \mathrm{sq} \mathrm{km}$ area illegally settled by farmers.

* In order to gather more information on encroachers, socio-demographic surveys were conducted (CARE/IFCP; Werikhe, 1991; Sucker, 1992). In June 1992 the Uganda Government signed a memorandum of understanding with representatives of the encroachers. It was agreed that the 2420 encroachers

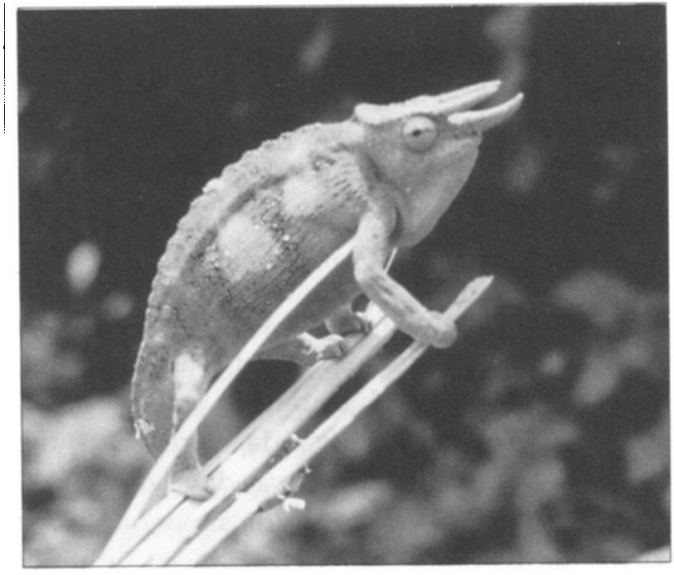

The Rwenzori three-horned chameleon Chamaeleo johnstoni is endemic to the Albertine Rift Afromontane Region. The recent creation of three mountain forest parks in Uganda greatly improves the long-term survival prospects for much of Uganda's biodiversity (Tom Butynski).

would harvest the remainder of their crops and relocate outside the park by the end of 1992. The government agreed to assist the encroachers during the relocation process and help them improve agricultural production. The encroachers have now left, more than 5100 indigenous trees have been planted in the encroached area, and the park boundary is clearly demarcated with signs, 180 stone and concrete markers, and a hedge of more than 51,700 shrubs and trees (K.-J. Sucker, pers. comm.).
West side of Mt Muhavura (4127 $\mathrm{m}$ ), one of the Virunga Volcanoes on which mountain gorillas occur. With the creation of the Mgahinga Gorilla National Park and Rwenzori Mountains National Park, all the alpine vegetation in the Albertine Rift Afromontane Region now lies within four national parks (Tom Butynski).

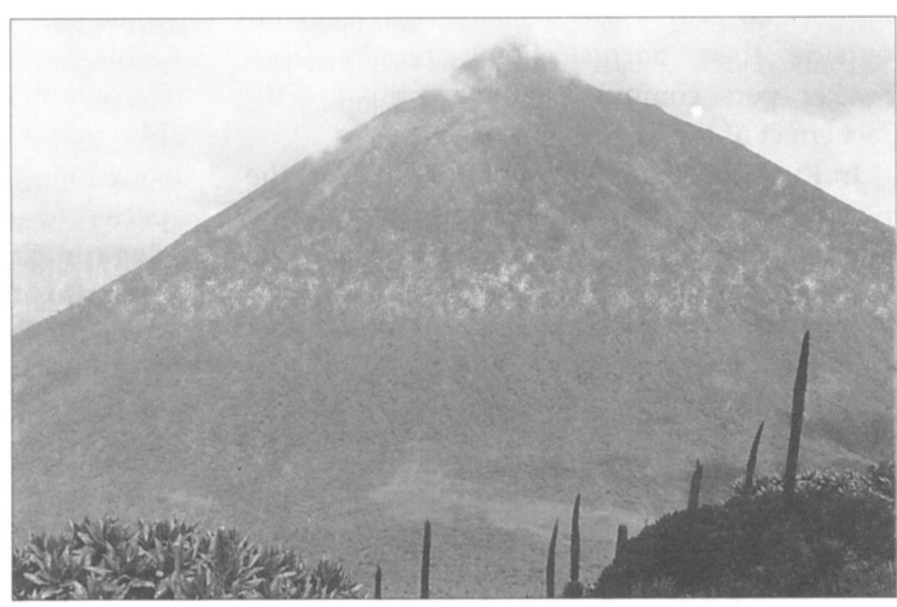


* A 'Reference for Management' for the park has been produced (Kalina, 1993), providing the background and scientific basis for the development of a management plan, which will be written in 1993/94.

\section{The effect of the civil war in Rwanda}

The most recent set-back to the proper management and development of the Mgahinga Gorilla National Park started in January 1991, when civil war in Rwanda spread to the Virunga Volcanoes. The Rwanda and Uganda portions of the Virunga Volcanoes, and the surrounding areas, have experienced fighting, artillery shelling, land mines and loss of human life. This situation continues to make it impossible for parks staff and project staff to carry out many of the planned conservation activities in and around the park, but they have done what they could. For example, land mines and other explosives were removed from the park in March 1993, making it possible for rangers to resume patrols of the entire park (K.-J. Sucker, pers. comm.)

Good communications are being maintained with the conservation authorities in Rwanda and Zaire, as well as with the government and army in Uganda, to help ensure minimum damage to the Mgahinga Forest, particularly the gorillas. To date, no gorillas are known to have died in the park as a result of the war but it is impossible for park rangers and biologists to visit all parts of the eastern Virungas. Since the beginning of the war, a number of gorilla groups have travelled far outside their normal home ranges (K.J. Sucker, pers. comm.). We believe this is a direct effect of the disturbances.

In Rwanda's Parc National des Volcans, the number of wire traps found was nearly twice as great during 1991 as during 1990 and the number of gorillas found caught in snares increased to at least eight. One of these died (Robbins, 1992). In May 1992, soldiers shot and killed one adult male gorilla in Rwanda.

Before the Rwanda Civil War, funds were obtained to establish a tourism programme at Mgahinga, which would include gorilla viewing, hikes up the volcanoes, nature walks, bird walks and 'golden monkey walks'. These activities will be implemented by Uganda National Parks and the Mgahinga Gorilla National Park Project once security returns to the area.

Other conservation/development activities include the establishment of a substation of the Institute of Tropical Forest Conservation, construction of a park headquarters and access roads, implementation of conservation education and agroforestry programmes outside the park, and establishing an ecological monitoring programme, particularly for the gorillas.

\section{Bwindi-Impenetrable National Park}

\section{Scenery and wildlife}

The Bwindi-Impenetrable National Park (formerly Bwindi-Impenetrable Forest Reserve and Animal Sanctuary) is located $25 \mathrm{~km}$ north of the Mgahinga Gorilla National Park (Figure 1). It covers $330 \mathrm{sq} \mathrm{km}$ and is one of the few forests in eastern Africa containing both lowland and montane forest in a continuum (1160-2600 m).

As a result of its size and altitudinal range, and its probable role as a Pleistocene refuge, the biodiversity of the forest is extremely high. Current evidence indicates that it is the richest forest in East Africa for trees (more than 160 species) (Hamilton, 1974, 1976; Butynski, 1984), ferns (more than 104 species) (Nakileza, 1993), birds (Keith et al., 1969; Keith, 1980; Kalina and Butynski, 1992), butterflies (Carcasson, 1964; Omoding, 1992), and probably many other taxa, including mammals (Kingdon, 1971). The forest contains many species of plants and birds not found elsewhere in East Africa, and many that are endemic to the Albertine Rift Afromontane Region. It has been selected by IUCN's Plants Programme as one of 29 forests most important for the conservation of Africa's plant diversity.

The bird list currently totals 346 species (J. Kalina and T. M. Butynski, 1992, unpubl. data). Seven of these are listed as vulnerable, rare, or 
near threatened (Collar and Stuart, 1985). The forest is of particular importance for the conservation of montane forest birds and Albertine Rift Afromontane Region endemics. At least 70 of the 78 montane forest bird species in the Albertine Rift Afromontane Region occur there (Keith, 1980), including 22 of the 27 species of birds endemic to the region (Dowsett-Lemaire and Dowsett, 1990).

A preliminary herpetological survey identified at least 28 species of amphibians (Drewes et al., 1992) and 28 species of reptiles (Greene, 1992) including some possibly new to science.

To date, 202 species of butterflies, eight of which are endemic to the Albertine Rift Afromontane Region, are known to occur in the forest (Omoding, 1992), which may be the most important in Africa for the conservation of montane butterflies (Carcasson, 1964).

J. Baranga (pers. comm.) lists 120 mammal species for the Bwindi-Impenetrable Forest. The most conspicuous are the primates (Butynski, 1984, 1985). Seven species of diurnal primates and at least three species of nocturnal primates occur. Of these l'Hoests monkey and chimpanzee are classified as vulnerable and the mountain gorilla as endangered (Lee et al., 1988).

\section{Conservation in the Bwindi-Impenetrable}

The IFCP started in August 1986 and is undertaking and promoting a large number of conservation activities in and around the BwindiImpenetrable Forest. The main funding for its work there has been provided by WWF and USAID, but significant support has also come from the FFPS, the International Primate Protection League, Berggorilla Patenschaft, Friends of Conservation, and the Embassies of Canada, Germany and the United States.

The following is a summary of the IFCP's more significant accomplishments in the Bwindi-Impenetrable Forest from August 1986 to April 1993.

* Working closely with National Parks, 40 park rangers and three wardens were selected and assigned to the forest. The high levels of illegal activities present in 1986 were virtually eliminated. Between August 1986 and March
1993,263 arrests were made and more than 4640 items confiscated, including 142 spears and 3559 wire traps. All gorilla and elephant poaching stopped.

* Several illegal schemes or poorly conceived development projects were brought to the government's attention. These schemes have either been abandoned or altered to reduce their negative environmental impact.

洸 The IFCP has assisted National Parks in demarcating the $112 \mathrm{~km}$ boundary and planting it with live tree markers. The IFCP also maintains $117 \mathrm{~km}$ of trails in the forest for law enforcement and research purposes.

* Three Ugandan students received MSc degrees and three are conducting MSc studies.

㳻 Project staff published 25 scientific papers and notes as well as reports and papers for the government.

* The government was lobbied successfully to upgrade the status of the forest to that of a national park.

* The IFCP purchased 12 ha of land near the main entrance of the park to establish a buffer zone in an area that otherwise might be negatively impacted by tourists and developers.

* The Institute of Tropical Forest Conservation (ITFC) was established to help preserve the biological diversity and ecological well-being of Uganda's forests, and to enhance the environmental quality of life for Ugandan people. The central facility consists of five main buildings and can sleep 60 people.

濚 The IFCP is assisting government and the International Gorilla Conservation Programme to implement the Bwindi-Impenetrable Forest Tourism Development Project, which started in October 1992.

\section{Development Through Conservation Project (DTCP) in Mgahinga and Bwindi- Impenetrable National Parks}

The DTCP was initiated by CARE, IFCP and WWF in 1988 with financial support from USAID. The primary goal is to contribute to the conservation of the Bwindi-Impenetrable and Mgahinga Forests. By 1996 it intends to help 9600 farming families living on sur- 
rounding land to improve the way they use their natural resources.

The following is a summary of the accomplishments of DTCP between October 1988 and April 1993.

* DTCP headquarters were established, including an office block, conservation education centre, and residence for the project manager.

* Fifty-five Conservation Extension Assistants (CEAs) were trained to serve as the main link between DTCP and the local people, providing conservation education and agroforestry inputs to the communities around the BwindiImpenetrable Forest, and holding about 100 meetings per month in schools, churches and markets.

* More than 150 tree nurseries and 600 woodlots were established. Each month 60,000100,000 seedlings are started, 20,000-25,000 are planted out and 100,000-200,000 tree seeds are distributed to farmers.

* Eight issues of the DTCP's conservation newsletter were produced in three languages and more than 1250 copies of each issue were widely distributed.

* Baseline data on the status, needs and agricultural practices of communities around the Bwindi-Impenetrable Forest were collected.

* Five Ugandan graduate students are now involved with ecological research/inventory projects or are taking MSc courses.

* Herbarium and ethnobotany programmes were developed and an ethnobotony garden planted for education and research purposes.

* DTCP and IFCP are assisting National Parks in the development of multiple-use activities in the Bwindi-Impenetrable Forest. Two surveys have been conducted on how the local communities utilize the BwindiImpenetrable Forest, the importance and impact of this utilization, and the conservation status of the species affected (Cunningham, 1992; Scott, 1992). National Parks is now establishing programmes that allow people to place beehives in the forest and remove some plant materials.

* DTCP and IFCP are working closely with National Parks and local communities to develop the first detailed management plan for the Bwindi-Impenetrable National Park.
Considerable importance is attached to community participation in this.

\section{Other conservation initiatives}

Population policy, family planning and health issues are closely related to the conservation of the region's natural forests. To complement the more direct conservation activities already taking place, CARE, with financial support from USAID, initiated the Community Reproductive Health Project in 1992. The objective of this project is to assist the Ministry of Health to introduce family planning services to the two districts around the Mgahinga and Bwindi-Impenetrable Forests. This project is being undertaken in collaboration with the United National Population Fund, Family Planning Association of Uganda, and others.

The IFCP, DTCP and National Parks are working with the World Bank, Uganda Government and others to establish the Bwindi-Impenetrable Forest Conservation Trust with funding from the World Bank/UNDP Global Environmental Facility $(\mathrm{GEF})$. The current plan is that funds generated by the Trust would be available, in perpetuity, for supporting projects designed to help conserve the biodiversity of the BwindiImpenetrable and Mgahinga Forests.

The Virunga Volcanoes in Rwanda are protected by a park which is also a UNESCO Biosphere Reserve while the park that protects the Zaire portions of the Virunga Volcanoes and the Rwenzori Mountains is also a UNESCO World Heritage Site. We are now encouraging the Government of Uganda to enhance further the conservation status of the Rwenzori Mountains, Mgahinga Gorilla and Bwindi-Impenetrable National Parks by establishing them as World Heritage Sites.

Uganda National Parks is now working to increase local support and co-operation by expanding the ways local people benefit from the parks. National Parks notes, however, that such utilization is a privilege, not a right, and that these activities are secondary to the maintenance of the park's balanced ecosystems and biodiversity (Kayanja, 1985).

While tourism has been, and probably will 
continue to be, the major multiple-use activity in Uganda's national parks, other activities are also permitted. These include research, fishing, bee-keeping, and the collection of minor products, such as medicinal plants and bush rope. Many surveys (for example, Butynski, 1984; Werikhe, 1991; Infield, 1989; Miskell, 1989; Cunningham, 1992; Scott, 1992) have been conducted in and around Uganda's parks in recent years to provide more information on the local people themselves, what materials they most want to extract from the parks, what the availability of these materials is, and how they can be removed with the least impact on the forest. The information collected is ultimately used to help National Parks set up various systems to control and monitor the off-take of products, and ensure that the benefits to the park are equitably distributed among the local people.

National Parks is currently developing revenue sharing systems whereby local communities will receive some of the revenue that a park generates. For example, the BwindiImpenetrable Forest Tourism Development Project is now working with National Parks, local government and local people to establish a system for distributing 20 per cent of tourism revenues to local communities.

\section{Summary}

The great conservation and economic values of the Rwenzori, Mgahinga and BwindiImpenetrable Forests are now widely recognized. The Government of Uganda, by establishing all three as national parks, has taken a major step towards ensuring that these values are not undermined. In addition, a total of eight conservation initiatives, supported by various international conservation/development organizations and agencies, are working effectively with government and local communities to ensure the long-term viability of these three national parks. Establishing sustainable use strategies and patterns for Uganda's three newest national parks remains an enormous task. The initiatives we have described above offer considerable hope for their future.

\section{Acknowledgments}

We thank Klaus-Jurgen Sucker for his unpublished data. Tom Struhsaker, Peter Howard and KlausJurgen Sucker made valuable comments on the manuscript. Permission for the authors to work in Uganda was kindly granted by the National Research Council, Office of the President, Forest Department, Game Department and National Parks. We are grateful for the generous support provided by FFPS and the other organizations and agencies acknowledged in the body of this paper.

\section{References}

Baranga, J. 1990. Representation of ecosystems in Uganda's protected areas: national parks. In Conservation of Biodiversity in Uganda (ed. D. Pomeroy), pp. 19-21. Proceedings of the Second Conservation Forum, Kampala.

Butynski, T.M. 1984. Ecological Survey of the Impenetrable (Bwindi) Forest, Uganda and Recommendations for its Conservation and Management. Unpubl. report to the Uganda Government. Wildlife Conservation International, New York.

Butynski, T.M. 1985. Primates and their conservation in the Impenetrable (Bwindi) Forest, Uganda. Primate Conserv. 6, 68-72.

Butynski, T.M. 1986. Status of elephants in the Impenetrable (Bwindi) Forest, Uganda. Afr. J. Ecol. 24, 189-193.

Butynski, T.M., Werikhe, S. and Kalina, J. In press. Status, distribution and conservation of the mountain gorilla in the Gorilla Game Reserve, Uganda. Primate Conserv.

Carcasson, R.H. 1964. A preliminary survey of the zoogeography of African butterflies. E. Afr. Wildl. J. 2, 122-157.

CARE/Impenetrable Forest Conservation Project. 1990. Socio-demographic Survey of the Encroached Area of the Proposed Mgahinga Gorilla National Park in South-west Uganda. Unpubl. report to the USAID-Uganda Mission.

Collar, N.J. and Stuart, S.N. 1985. Threatened Birds of Africa and Related Islands. The ICBP/IUCN Red Data Book, Part I. Cambridge, UK.

Cunningham, A.B. 1992. People, Park and Plant Use: Research and Recommendations for Multiple-use Zones and Development Alternatives around BwindiImpenetrable National Park, Uganda. Unpubl. report to CARE-Uganda, Kampala

Dowsett-Lemaire, F. and Dowsett, R.J. 1990. Zoogeography and taxonomic relationships of the forest birds of the Albertine Rift Afromontane Region. Tauraco Research Report, 3, 87-109.

Drewes, R.C., Vindum, J.V. and O'Brien, J.P. 1992. 
Amphibians of the Impenetrable Forest, Uganda. A report for CARE-Uganda, Kampala.

FAO and UNEP. 1981. Forest Resources of Tropical Africa. Part II: Country Briefs, UN 32/6. 1301-78-04 Technical Report 2. Rome.

Greene, H.W. 1992. Reptiles of the Bwindi Forest Preserve, Uganda. A preliminary report for CAREUganda, Kampala.

Hamilton, C.A. 1974. Distribution patterns of forest trees in Uganda and their historical significance. Vegetatio, 29, 21-35.

Hamilton, C.A. 1976. The significance of patterns of distribution shown by forest plants and animals in tropical Africa for the reconstruction of upper Pleistocene palaeo-environments: a review. Palaeoecol. Afr. 9, 63-97.

Hamilton, C.A. 1984. Deforestation in Uganda. Oxford University Press, Nairobi.

Howard, P.C. 1991. Nature Conservation in Uganda's Tropical Forest Reserves. IUCN, Gland, Switzerland.

Infield, M. 1989. Socio-economic Survey in the Queen Elizabeth National Park, Uganda. Unpubl. report to Uganda National Parks. Agriconsulting, Rome.

Kalina, J. 1993. Mgahinga Gorilla National Park: Reference for Management. Unpubl. report to the Uganda Ministry of Tourism, Wildlife and Antiquities. CARE, Kampala.

Kalina, J. and Butynski, T.M. 1992. Bird List for the Impenetrable (Bwindi) Forest National Park. Unpubl. report to CARE and WWF, Kampala.

Kayanja, F.I.B. 1985. National Parks policy. In Report on the Seminar on Renewable Natural Resources, Ecology and Conservation (ed. D. K. Etoori). Ministry of Planning and Economic Development, Kampala.

Keith, S. 1980. The avifauna of the Impenetrable Forest, Kigezi, Uganda with special reference to altitudinal distribution. Proceedings IV Pan-African Ornithological Congress, pp. 159-167.

Keith, S., Twomey, A., Friedman, H. and Williams, J. 1969. The avifauna of the Impenetrable Forest, Uganda. Am. Mus. Novit. No. 2389, 1-41.

Kingdon, J. 1971. East African Mammals: An Atlas of Evolution in Africa. Academic Press, New York.

Langdale-Brown, I., Osmaston, H.A. and Wilson, J.G. 1964. The Vegetation of Uganda. Government Printer, Entebbe.

Lee, P.C., Thornback, J. and Bennett, E.L. 1988. Threatened Primates of Africa. The IUCN Red Data Book. IUCN Gland, Switzerland.

MacKinnon, J. and MacKinnon, K. 1986. Review of the Protected Areas System in the Afrotropical Realm. IUCN, Gland, Switzerland.

Malpas, R.C. and Infield, M.M. 1981. The Mgahinga Forest and Gorilla Game Reserves, Uganda. Unpubl. report to the Uganda Ministries of Tourism and Wildlife, and Agriculture and Forestry, Kampala.
Miskell. J. 1989. Fuelwood Supply for Fishing Villages in the Queen Elizabeth National Park, Uganda. Unpubl. report to Uganda National Parks. Agriconsulting, Rome.

Nakileza, R.B. 1993. The Distribution and Status of Pteridophytes (ferns) in the Impenetrable Forest. MSc thesis, Makerere University, Kampala.

Omoding, J. 1992. Status, Distribution and Ecology of the Butterfly Fauna of the Impenetrable Forest, Southwestern Uganda. MSc thesis, Makerere University, Kampala.

Osmaston, H.A. and Pasteur, D. 1972. Guide to the Rwenzori. Mountain Club of Uganda, Kampala.

Robbins, M. 1992. The effects of the war on the Virunga mountain gorilla population. Gorilla Gazette, 6, 1-2.

Scott, P. 1992. Fringe Benefits. National Park Boundaries as Areas for Local Community Utilization: The Case of the Impenetrable (Bwindi) Forest, Uganda. Unpubl. report to Uganda National Parks, Kampala.

Sholley, C.R. 1990. 1989 Census of Mountain Gorillas in the Virungas of Central Africa. Unpubl. report, Kigali.

Struhsaker, T.T. 1987. Forestry issues and conservation in Uganda. Biol. Cons. 39, 209-234.

Sucker, K.-J. 1992. Information on Encroachment in Zone 2 of Mgahinga Gorilla National Park. Unpubl. report to Uganda National Parks, Kampala.

Tabor, G.M., Johns, A.D. and Kasenene, J.M. 1990. Deciding the future of Uganda's tropical forests. Oryx, 24, 208-214.

UNEP. 1988a. Strategic Resources Planning in Uganda: Natural Resources and Environment in Uganda. UNEP, Nairobi.

UNEP. 1988b. Strategic Resources Planning in Uganda: Vol. III, Forests. UNEP, Nairobi.

UNEP. 1988c. Strategic Resources Planning in Uganda: Vol. X, Human Settlements. UNEP, Nairobi.

Werikhe, S. 1991. An Ecological Survey of the Gorilla Game Reserve, South-West Uganda. MSc thesis, Makerere University, Kampala.

World Bank. 1985. Population Growth and Policies in Sub-Saharan Africa. World Bank, Washington.

Yeoman, G. 1992. Uganda's new Rwenzori National Park. Swara, 15, 16-22.

Thomas M. Butynski, World Wide Fund for Nature, Institute of Tropical Forest Conservation, $\mathrm{PO}$ Box 7487, Kampala, Uganda.

Jan Kalina, Development Through Conservation Project, CARE-Uganda, PO Box 7280, Kampala, Uganda. 